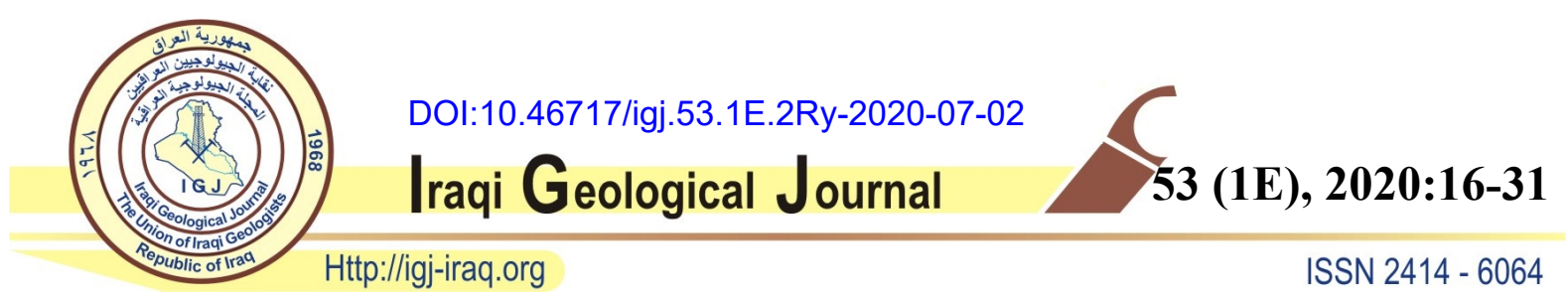

\title{
VARIATION OF SATURATION PRESSURE VALUES IN MISHRIF AND ZUBAIR RESERVOIRS IN RUMAILA OILFIELD, SOUTHERN IRAQ
}

\author{
${ }^{1}$ Nada Shaker, ${ }^{1}$ Hayder K. Al-Mayyahi" and ${ }^{1}$ Hussein Saeed Al-Malikee \\ Basrah Oil Company \\ *E-mail:Halmayyahi@gmail.com \\ Received: 26 September 2019; accepted: 14 May 2020
}

\begin{abstract}
Reservoir fluid, pressure volume temperature properties such as bubble point pressure, gas solubility, oil and gas formation volume factors, and viscosities are important elements in the reservoir management and field development. Therefore, this study aims to distribute the bubble point pressure on the main oil reservoirs in the Rumaila oilfield, laboratories tests results from 103 pressure volume temperature reports were used, these tests were obtained from the Mishrif, Upper Shale and Main pay reservoirs. Pressure gradient in the study area was defined using Surfer14 software, and in order to avoid the variation of low-pressure areas in the future drilling wells plan, continuous monitoring and focus on these areas, pressure maps were drawn then reading graduation of pressure on these maps to obtain final formula to adopt a specific range of saturation pressures values and distribute them among Rumaila oilfield. The study also compares between the main sub-units of the Main pay reservoir and Mishrif reservoir in the North Rumaila and other reservoirs in the South Rumaila oilfield as well as to define other factors in pressure volume temperature reports such as gas oil ratio, viscosity and formation volume factor that contribute to the saturation pressure variation.
\end{abstract}

Keywords: Pressure volume temperature; Gas oil ratio; Formation factor

\section{INTRODUCTION}

Rumaila is the largest oilfield in Iraq, it is located $50 \mathrm{~km}$ west of Basra city, Southern Iraq (Fig. 1). Covering an area of $1,800 \mathrm{~km}^{2}$. The field was discovered in 1953 and been operated in 1972 , with oil reserves of about 17 billion barrels (Basra oil company 2016). Reservoir fluid, pressurevolume temperature (PVT) properties (such as bubble point pressure), gas solubility, oil and gas formation volume factors and viscosities are critical in the reservoir engineering management and computations (Vetter and Farone, 1987). 


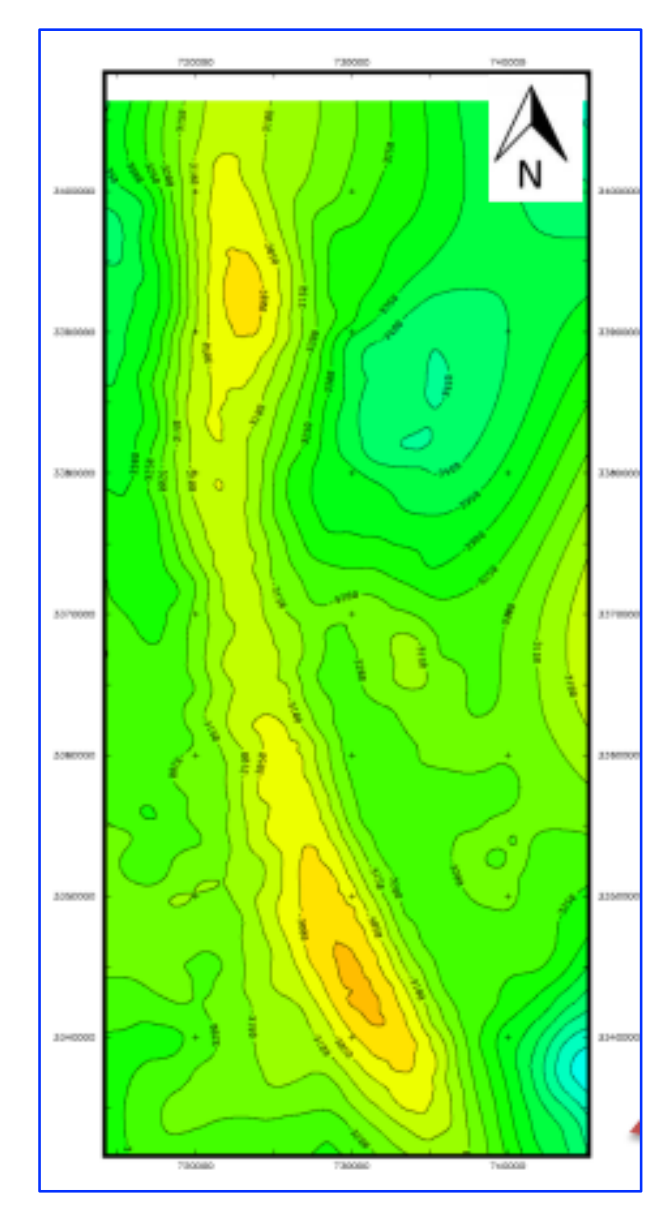

B

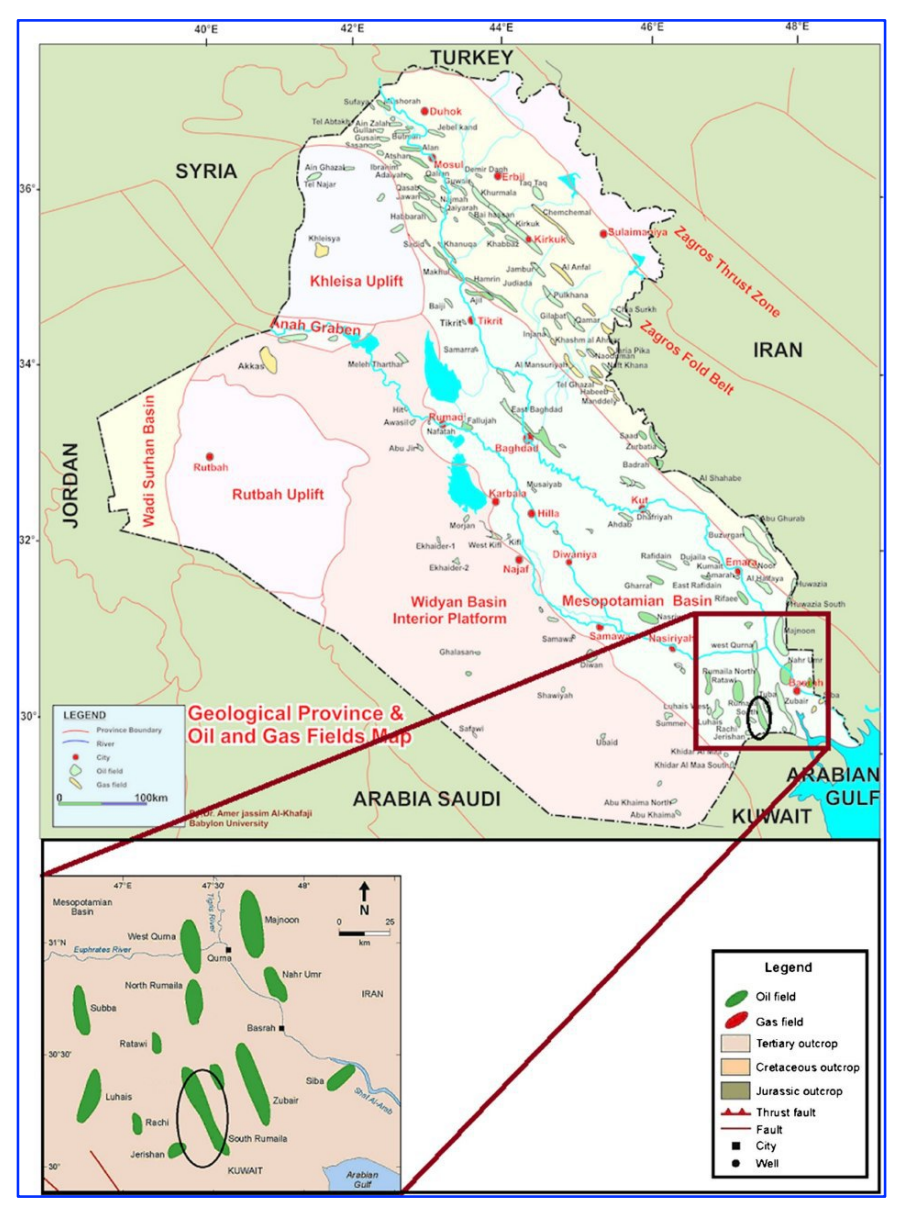

A

Fig. 1. (A) Location map of the Rumaila Oilfield after (Al-Mudhafar, 2017) (B) Rumaila structure map (Almayyahi and Aljaberi, 2018)

These PVT properties are required to obtain the initial hydrocarbons in place, optimum production schemes, ultimate hydrocarbon recovery, material balance calculations, well test analysis, design of fluid handling equipment, and reservoir volumetric estimates. Bubble point pressures $(\mathrm{Pb})$ and gas solubility $(\mathrm{Rs})$ are two of the most critical parameters used to characterize an oil reservoir (BP, 2013), as they play a vital role in the reservoir management and reservoir simulation. Therefore, the accurate determination of these properties is one of the main challenges in reservoir development and management. The oil formation volume factor is important in the primary and subsequent development of any oil field (Karim, 1992).

The Zubair reservoir consists of several zones of varying reservoir quality and compartment with unknown connectivity. Primary depositional factors-grain size and ductile content - are the main controls on reservoir quality within the Zubair Formation. It is important to note that these depositional factors are relative controls on reservoir quality, with mechanical compaction following deposition and burial responsible for the loss of initial porosity (Arif and 
Khaffaf, 1979). The investigation studies and seismic surveys of the Mesopotamian Zone are carried by the Iraqi Oil Company demonstrated the existence of many subsurface structures generally N-S trending anticlines and synclines of different sizes (Morad et al., 1989). The Mishrif reservoir in Rumaila Oilfield is structurally trapped by an elongated double anticline, Northern trends N-S, the southern trends NNW to SSE, (BP, 2013). Change in orientation is likely to be related to a deep-seated fault in the saddle area. The two domes are separated by a saddle, which also roughly divides North Rumaila from South Rumaila. Structural dips are relatively low and do not exceed more than 5 degrees. Many wells were drilled in Rumaila oilfield since 1973 to determine the structural configuration and facies distribution of the reservoir rocks (BP, 2013). Rumaila oilfield represents a gentle anticline fold and the main producing formations in this field are Zubair, Nahr Umr and Mishrif formations (Al-Mimar and Awadh, 2019). The bubble-point pressure of a hydrocarbon system is defined as the highest pressure at which a bubble of gas is first liberated from the oil (Ahmed, 2018). The bubblepoint pressure is a strong function of gas solubility, gas gravity, oil gravity, and temperature.

(Al-Jafar and Al-Jaberi, 2019) mentioned that Zubair oil Field is one of the most important oil fields in the southern part of Iraq. It is an anticline structure which has a NNW - SSE trend axis. It has four domes from south to north (Safwan, Rafdhyia, Shuaiba and Hammar) respectively as it is familiar in previous study. This study aims to distribute the bubble point pressure on the main oil reservoirs in Rumaila oilfield to avoid the low-pressure areas in future drilling wells plan, continuous monitoring and focus on these areas.

\section{METHODOLOGY}

The main steps of methodology for this research can be summarized as follows:

1. A database of 86 thermodynamic study and physical properties of the reservoir fluids for the wells in all Rumaila reservoirs have been prepared (Table 1) from 103 thermodynamic study and physical properties available, although they are repeated study about the same available wells, the latest study was adopted in this research.

2. Plot the bubble-point pressure, GOR, gas gravity $\gamma$ g, oil gravity API, Bo viscosity of oil and temperature tests for the Mishrif and main pay reservoir in North Rumaila and upper shale reservoir in South Rumaila, implemented for all those reservoir and sub-units of Main pay (DJ, LN, ABDJ, and ABDJLN).

3. Collecting and processing thermodynamic study and physical properties data to prepare mathematical relationships between (PVT) factors. Moreover, Surfer 14 software used for mapping the distribution of saturation pressure for all of the reservoir units. 
Table 1. Physical laboratory test results for the identified reservoirs at wells drilled in Rumaila Oilfield (after unpublished report from Basra Oil Company)

\begin{tabular}{|c|c|c|c|c|c|c|c|c|c|c|c|c|}
\hline well & Res. & Unit & Date & $\begin{array}{l}\text { Depth } \\
\text { (m) } \\
\text { (KB) }\end{array}$ & $\operatorname{Pr}(\mathrm{psi})$ & $\begin{array}{l}\text { Bo@ } \\
\text { Psat. }\end{array}$ & $\begin{array}{l}\text { Psat } \\
\text { (psi) }\end{array}$ & API & $\begin{array}{c}\text { GOR } \\
\text { (SCF/STB) }\end{array}$ & $\begin{array}{c}\text { Visco. } \\
\text { (cp) } \\
\text { @ Psat. }\end{array}$ & $\begin{array}{c}\text { Sp.Gr@ } \\
\text { Psat. }\end{array}$ & $\begin{array}{l}\text { B.H.T } \\
\left({ }^{\circ} \mathrm{C}\right)\end{array}$ \\
\hline $\mathrm{Ru}-71$ & Mishrif & & 1976 & 2050 & & 1.2914 & 2118.8 & 26.9 & 502.81 & 1.9848 & 0.843 & 76.7 \\
\hline Ru-29 & Mishrif & & 1977 & 2320 & & 1.354 & 2431.6 & 26.7 & 604.27 & 1.42 & 0.7699 & 79 \\
\hline Ru-105 & Mishrif & & 1978 & 2487 & 3884.9 & 1.3082 & 1874.2 & 24.3 & 464.61 & & 0.7796 & 86.7 \\
\hline R-097 & Mishrif & & 1976 & 2248 & 3697.2 & 1.3081 & 2147.2 & 26.9 & 522.53 & 1.285 & 0.8296 & 78.9 \\
\hline R-041 & Mishrif & & & 2200 & 3597.7 & 1.3527 & 2545.4 & 25.5 & 594.72 & 1.709 & 0.7563 & 76.7 \\
\hline R-074 & Mishrif & & & 2170 & 3498.1 & 1.3344 & 2353.4 & 25.2 & 581.12 & 1.619 & 0.7508 & 76.7 \\
\hline R-088 & Mishrif & & & 2192 & 0 & 1.3468 & 2431.6 & 25.2 & 603.54 & \begin{tabular}{|l|}
1.397 \\
\end{tabular} & 0.7807 & 76.6 \\
\hline R-020 & Mishrif & & 1977 & 2136 & 0 & 1.3817 & 2424.5 & 27.3 & 872.36 & 1.047 & 0.7893 & 79.4 \\
\hline R-059 & Mishrif & & 1977 & 2108 & 0 & 1.3635 & 2389 & 25.2 & 613.88 & 1.48 & 0.8363 & 79.4 \\
\hline R-081 & Mishrif & & 1977 & 2286 & 3498.1 & 1.3099 & 2410.3 & 25.9 & 582.02 & 1.198 & 0.7778 & 76.7 \\
\hline R-081 & Mishrif & & 1977 & 2182 & 0 & 1.3276 & 2488.5 & 27 & 591.63 & & & \\
\hline R-041 & Mishrif & & 1978 & & 3697.2 & 1.3129 & 2296.5 & 25.8 & 583.15 & 1.01 & 0.7704 & 76.7 \\
\hline R-140 & Mishrif & & 1979 & 2180 & 2986.2 & 1.4076 & 2346.3 & 27.2 & 661.07 & 0.877 & & 76.4 \\
\hline $\mathrm{R}-124$ & Mishrif & & 1979 & 2275 & 3199.5 & 1.3204 & 2040.6 & 24.9 & 512.36 & 1.325 & 0.7329 & 76.7 \\
\hline $\mathrm{R}-124$ & Mishrif & & 1979 & 2237.7 & 3469.7 & 1.3733 & 2061.9 & 25.6 & 532.81 & 1.14 & 0.7708 & 76.7 \\
\hline $\mathrm{R}-410$ & Mishrif & & 1986 & 2430 & 0 & 1.2477 & 1813.1 & 23.5 & 426.97 & 1.814 & 0.877 & 76.7 \\
\hline R-170 & Mishrif & & 2007 & 2195 & 3953.2 & 1.023 & 2317.9 & 26.4 & 531.07 & & 0.7441 & 75 \\
\hline $\mathrm{R}-334$ & Mishrif & & 2007 & 2295.5 & 2699 & 1.3052 & 2104.6 & 26.5 & 482.25 & & 0.7379 & 77 \\
\hline R-046 & Mishrif & & 1974 & 2235 & & & 2278 & & 0 & & & 74 \\
\hline $\mathrm{R}-046$ & Mishrif & & 1974 & & & 1.37 & 2303 & & 619.44 & 1.358 & & 74 \\
\hline $\mathrm{R}-046$ & Mishrif & & 1975 & & & 1.3386 & 2365 & 26.3 & 589.1 & 1.4135 & & 71 \\
\hline R-062 & Mishrif & & 1975 & & & 1.3595 & 2320 & 25.1 & 589.83 & 2.155 & & 72 \\
\hline $\mathrm{R}-083$ & Mishrif & & 1975 & & & & & 24.2 & 603.37 & 1.55 & & 77 \\
\hline R-044 & Zubair & DJ+LN & 1977 & & & 1.3854 & 2104.6 & 28 & 550.56 & 0.85 & 0.8147 & 99 \\
\hline R-047 & Zubair & DJ & 1976 & 3141 & 3896.3 & 1.5763 & 2900.9 & 32.6 & 893.26 & \begin{tabular}{|l|}
0.549 \\
\end{tabular} & 0.8548 & 99 \\
\hline R-049 & Zubair & $\mathrm{DJ}+\mathrm{LN}$ & 1977 & & 0 & 1.4116 & 2360.5 & 28 & 629.21 & \begin{tabular}{|l|}
0.952 \\
\end{tabular} & 0.8025 & 99 \\
\hline R-051 & Zubair & LN & 1977 & 3243 & 3995.8 & 1.3698 & 2204.1 & 29 & 573.03 & 1.192 & 0.7903 & 99 \\
\hline R-052 & Zubair & $\mathrm{DJ}+\mathrm{LN}$ & 1977 & & 3498.1 & 1.433 & 2524.1 & 25 & 655.96 & 0.972 & 0.8001 & 99 \\
\hline R-056 & Zubair & $\mathrm{LN}$ & 1977 & & 0 & 1.3563 & 2005 & 28 & 522.47 & 1.023 & 0.8065 & 99 \\
\hline R-057 & Zubair & $\mathrm{LN}$ & 1977 & 3189 & 0 & 1.3872 & 2666.3 & 26 & 640.45 & 0.922 & 0.772 & 99 \\
\hline R-059 & Mishrif & & 1977 & & 0 & 1.3635 & 0 & 25 & 613.88 & & & 79.4 \\
\hline R-062 & Zubair & $\mathrm{LN}$ & 1977 & & 3697.2 & 1.3643 & 1898.4 & 26.6 & 526.97 & 1.133 & & 98 \\
\hline R-070 & Zubair & LN & 1978 & 3227 & 0 & & 2282.3 & 26 & 606.74 & 0.691 & & 98.9 \\
\hline R-071 & Zubair & $\mathrm{AB}+\mathrm{DJ}$ & 1978 & 3700 & 0 & 1.3532 & 1976.6 & 28.5 & 507.3 & 0.85 & 0.8188 & 98.9 \\
\hline R-072 & Zubair & $\mathrm{LN}$ & 1978 & 3242 & 0 & 1.3727 & 2111.7 & 28 & 538.76 & & 0.7888 & \\
\hline R-076 & Zubair & & 1978 & 3101 & 3500 & 1.6058 & 3171.1 & 34.2 & 991.85 & \begin{tabular}{|l|}
0.409 \\
\end{tabular} & & 98.9 \\
\hline R-077 & Zubair & $\mathrm{AB}+\mathrm{DJ}$ & 1978 & 3157 & 3800 & 1.6307 & 3092.9 & 33.9 & 1016.9 & 0.374 & 0.8205 & 98.9 \\
\hline R-082 & Zubair & LN & 1977 & 3207.5 & & 1.4852 & 2588 & 30.4 & 719.89 & 0.638 & 0.808 & 98.9 \\
\hline R-009 & Zubair & $\mathrm{AB}+\mathrm{DJ}+\mathrm{LN}$ & 1974 & 3249 & 4267 & 1.4919 & 2490 & 31 & 738.76 & 0.58 & 0.9611 & 99 \\
\hline R-030 & Zubair & $\mathrm{AB}+\mathrm{DJ}$ & 1974 & 3194 & & 1.5278 & 0 & 34 & 882.02 & & & 99 \\
\hline R-033 & Zubair & $\mathrm{AB}+\mathrm{LN}$ & 1974 & 3194 & & 1.458 & 2332.1 & & 640.45 & & & \\
\hline R-036 & Zubair & DJ+LN & 1974 & 3091 & 4330 & 1.3637 & 2231.1 & 28.5 & 589.89 & \begin{tabular}{|l|}
0.847 \\
\end{tabular} & & 99 \\
\hline R-039 & Zubair & DJ+LN & 1975 & 3214 & 4300 & 1.4228 & 2315 & 32 & 643.76 & 0.586 & 0.7927 & 99 \\
\hline R-043 & Zubair & $\mathrm{AB}+\mathrm{DJ}+\mathrm{LN}$ & & 3121 & 4370 & 1.3387 & 1868.5 & 27.6 & 470.22 & 0.866 & 0.785 & 99 \\
\hline R-045 & Zubair & DJ & 1974 & 3264 & 4150 & & 2669.1 & 30.9 & 814.61 & 0.593 & 0.8135 & \\
\hline R-040 & Zubair & & 1994 & 3188 & & 1.4414 & 2246.8 & 32.7 & 658.99 & 0.502 & 0.7451 & 99 \\
\hline R-050 & Zubair & DJ+LN & 1976 & 3244 & & 1.2909 & 2170 & 28.4 & 574.78 & \begin{tabular}{|l|}
0.921 \\
\end{tabular} & 0.8249 & 99 \\
\hline R-051 & Zubair & $\mathrm{AB}+\mathrm{DJ}$ & & 3070 & 3948.9 & 1.5473 & 2175.7 & 34.1 & 847.87 & 0.572 & 0.8081 & 99 \\
\hline R-055 & Zubair & LN & 1976 & 3164.6 & & 1.4144 & 2253.9 & 27.9 & 603.37 & 0.912 & 0.927 & 99 \\
\hline $\mathrm{R}-058$ & Zubair & DJ & & 3077 & & 1.6344 & 2969.1 & 33.6 & 996.46 & 0.478 & 0.8053 & \\
\hline R-060 & Zubair & $\mathrm{LN}$ & 1976 & 3218.7 & & 1.4206 & 2279.5 & 30.5 & 638.76 & \begin{tabular}{|l|}
0.739 \\
\end{tabular} & 0.8025 & 99 \\
\hline R-061 & Zubair & $\mathrm{LN}$ & 1976 & & & 1.404 & 2325 & 30.9 & 621.74 & 0.72 & 0.7878 & 99 \\
\hline R-063 & Zubair & $\mathrm{AB}$ & 1975 & 3234 & & 1.4799 & 2654.9 & 31.9 & 779.78 & 0.555 & 0.8489 & 99 \\
\hline R-065 & Zubair & DJ & 1976 & 3022 & & 1.612 & 3074.4 & 34.2 & 986.97 & 0.433 & 0.8153 & 99 \\
\hline R-067 & Zubair & $\mathrm{LN}$ & 1975 & 3240 & & 1.039 & 2104.6 & 28 & 559.49 & \begin{tabular}{|l|}
0.957 \\
\end{tabular} & 0.8144 & 99 \\
\hline R-077 & Zubair & $\mathrm{LN}$ & 1975 & 3052 & & 1.4149 & 2239.7 & & 628.15 & 0.69 & 0.8168 & \\
\hline R-078 & Zubair & & 1975 & 3253 & & 1.6296 & 3169.6 & 32.8 & 976.4 & 0.638 & 0.8001 & 107 \\
\hline R-079 & Zubair & $\mathrm{LN}$ & 1976 & 3248 & & 1.3844 & 2104.6 & 27.7 & 565.17 & 0.958 & 0.8059 & 99 \\
\hline
\end{tabular}




\begin{tabular}{|c|c|c|c|c|c|c|c|c|c|c|c|c|}
\hline R-040 & Zubair & $\mathrm{AB}+\mathrm{DJ}$ & $\mid 1976$ & 3226 & & 1.6033 & 2954.9 & 32.9 & 934.61 & $\mid 0.464$ & 0.8268 & 99 \\
\hline R-001 & Zubair & $\mathrm{AB}+\mathrm{DJ}$ & 1991 & 3190 & & 1.5264 & 2644.9 & 33.2 & 801.4 & 0.583 & 0.8467 & 99 \\
\hline R-002 & Zubair & & 2000 & 3202 & & 1.4587 & 2374.7 & 32.9 & 681.46 & 1.043 & 0.7683 & 99 \\
\hline R-013 & Zubair & & 2000 & 3139.5 & & 1.5148 & 2730.2 & 32.4 & 791.57 & 1.121 & 0.7211 & 99 \\
\hline $\mathrm{R}-013$ & Zubair & $\mathrm{AB}+\mathrm{DJ}$ & \begin{tabular}{|l|}
2009 \\
\end{tabular} & 3140 & & 1.5187 & 2744.5 & 32.7 & 806.74 & & 0.7738 & 99 \\
\hline R-019 & Zubair & DJ & \begin{tabular}{|l|}
1992 \\
\end{tabular} & 3234 & & 1.4012 & 2545.4 & 31.8 & 704.1 & 0.84 & 0.7937 & 99 \\
\hline R-023 & Zubair & $\mathrm{AB}+\mathrm{DJ}$ & \begin{tabular}{|l|}
1978 \\
\end{tabular} & & 3199.5 & & 2808.5 & 32.3 & 780.9 & 0.595 & 0.8416 & \\
\hline R-035 & Zubair & $\mathrm{AB}+\mathrm{DJ}+\mathrm{LN}$ & 1992 & 3172 & & 1.4196 & 2246.8 & 29 & 617.98 & 0.875 & 0.7828 & 99 \\
\hline R-037 & Zubair & $\mathrm{AB}+\mathrm{DJ}$ & \begin{tabular}{|l|}
1993 \\
\end{tabular} & 3170 & 4322 & 1.3665 & 2019.2 & 27.9 & 540.73 & 0.699 & 0.809 & 99 \\
\hline R-040 & Zubair & $\mathrm{AB}+\mathrm{DJ}$ & 1994 & 3188 & & 1.4434 & 2246.8 & 32.7 & 658.99 & 0.502 & 0.7451 & 99 \\
\hline R-042 & Zubair & & 2000 & 3433 & \begin{tabular}{|l|}
4670 \\
\end{tabular} & 1.3593 & 2118.8 & 28.2 & 522.02 & 1.08 & 0.7902 & 99 \\
\hline R-043 & \begin{tabular}{|l|} 
U.Sh. \\
\end{tabular} & & \begin{tabular}{|l|}
1993 \\
\end{tabular} & 3109 & & 1.3422 & 1933.9 & 27.5 & 478.93 & 0.866 & 0.7457 & 99 \\
\hline $\mathrm{R}-053$ & Zubair & LN & \begin{tabular}{|l|}
1978 \\
\end{tabular} & 3106 & 3200 & 1.3733 & 1993.6 & 28.8 & 528.2 & 0.832 & 0.8236 & 99 \\
\hline R-054 & Zubair & & 2008 & & 3863 & 1.0349 & 2189.9 & 33.5 & 644.78 & & 0.7881 & 99 \\
\hline R-058 & Zubair & $\mathrm{AB}+\mathrm{DJ}$ & 1994 & 3137 & & 1.5443 & 2943.5 & 33.7 & 864.49 & & 0.7799 & 99 \\
\hline R-065 & Zubair & DJ & \begin{tabular}{|l|}
1994 \\
\end{tabular} & 3115 & & 1.5173 & 2772.9 & 34 & 797.36 & & 0.7785 & 99 \\
\hline R-066 & Zubair & DJ & 1978 & 3144 & 3299 & 1.444 & 2389 & 29.3 & 650.96 & & 0.855 & 99 \\
\hline R-068 & Zubair & DJ & \begin{tabular}{|l|}
1978 \\
\end{tabular} & & 0 & 1.61 & 3071.5 & 35.3 & 966.29 & 0.533 & 0.8498 & 99 \\
\hline R-070 & Zubair & $\mathrm{AB}$ & 1993 & & 2900.9 & 1.544 & 2900.9 & 34.4 & 878.48 & 0.452 & 0.7678 & 99 \\
\hline $\mathrm{R}-073$ & Zubair & DJ & \begin{tabular}{|l|}
1878 \\
\end{tabular} & 3214 & 0 & 1.5647 & 2922.2 & 33.6 & 897.75 & & 0.8403 & 99 \\
\hline R-139 & Zubair & & 1979 & 3110 & 3700 & 1.5837 & 3071.5 & 32.9 & 939.16 & 0.426 & 0.7872 & 99 \\
\hline R-114 & Zubair & & \begin{tabular}{|l|}
1979 \\
\end{tabular} & 3116 & 4095.4 & 1.2911 & 2110.2 & 25.3 & 411.8 & 1.132 & 0.7652 & 99 \\
\hline R-163 & Zubair & & 1992 & 3141 & 4749.5 & 1.511 & 2701.8 & 33.7 & 836.8 & 0.3 & 0.7994 & 99 \\
\hline R-169 & Zubair & $\mathrm{AB}+\mathrm{DJ}+\mathrm{LN}$ & \begin{tabular}{|l|}
1994 \\
\end{tabular} & 3289 & 0 & 1.5546 & 2787.1 & & 870.1 & & 0.7686 & 99 \\
\hline R-188 & Zubair & $\mathrm{AB}+\mathrm{DJ}$ & 1993 & 3179 & 4365.5 & 1.5525 & 2957.8 & 33.5 & 938.03 & 0.867 & 0.8302 & 99 \\
\hline R-199 & Zubair & $\mathrm{AB}+\mathrm{DJ}+\mathrm{LN}$ & 1994 & 3185 & 0 & 1.4213 & 1948.1 & 31.8 & 586.12 & 0.425 & 0.7641 & 99 \\
\hline $\mathrm{R}-201$ & Zubair & DJ & \begin{tabular}{|l|}
1993 \\
\end{tabular} & 3133 & 0 & 1.5566 & 3043.1 & 33.6 & 948.37 & & 0.7872 & 99 \\
\hline $\mathrm{R}-220$ & Zubair & $\mathrm{AB}+\mathrm{DJ}$ & 1993 & 3204 & 4577.4 & 1.4348 & 2374.7 & 31.2 & 675.67 & \begin{tabular}{|l|}
0.798 \\
\end{tabular} & 0.8183 & 99 \\
\hline Ru-009 & Zubair & U.SH.M & 1984 & 3045.5 & & 1.4273 & 2147.2 & 29.4 & 510.11 & 0.642 & 0.7743 & 99 \\
\hline Ru-015 & Zubair & U.SH.M & 1984 & & 0 & 1.3993 & 1535.8 & 26.3 & 465.34 & 1.02 & 0.7615 & 99 \\
\hline $\mathrm{Ru}-023$ & Zubair & DJ & \begin{tabular}{|l|}
1977 \\
\end{tabular} & 3200 & 0 & 1.4452 & 2602.3 & 30.8 & 739.61 & \begin{tabular}{|l|l|}
0.651 \\
\end{tabular} & 0.8152 & 99 \\
\hline Ru-32 & Zubair & & 1978 & 3100 & 0 & 1.5937 & 2872.4 & 33.1 & 930.45 & 0.421 & & \\
\hline Ru-063 & Zubair & LN & 1977 & & 0 & 1.5045 & 2580.9 & 33.3 & 780.39 & 0.561 & 0.789 & 99 \\
\hline Ru-64 & Zubair & $\mathrm{AB}+\mathrm{DJ}$ & 1984 & 3141 & 0 & 1.4985 & 2374.7 & 32.1 & 673.09 & 0.523 & 0.8154 & 99 \\
\hline Ru-065 & Zubair & $\mathrm{USM}+\mathrm{mp}$ & & 3140 & 0 & & 2488.5 & 32.4 & 702.64 & & & 99 \\
\hline $\mathrm{Ru}-65$ & Zubair & U.SH.M & \begin{tabular}{|l|}
1977 \\
\end{tabular} & 3100 & 4921.5 & 1.4862 & 2545.4 & 31.7 & 738.71 & 0.62 & 0.8296 & 99 \\
\hline Ru-067 & Zubair & U.SH.M & \begin{tabular}{|l|}
1978 \\
\end{tabular} & 3100 & 5033.9 & 1.4042 & 2417.4 & 32.3 & 0 & 0.65 & 0.7905 & 99 \\
\hline $\mathrm{Ru}-072$ & Zubair & L.ss.m & & & 0 & 1.4992 & 2559.6 & 27.7 & 682.58 & 0.705 & 0.8144 & 104 \\
\hline Ru-074 & Zubair & U.SH.M & \begin{tabular}{|l|}
1978 \\
\end{tabular} & 3155 & 4271.1 & 1.5356 & 2552.5 & 30.9 & 782.02 & 0.81 & 0.732 & 99 \\
\hline Ru-078 & Zubair & U.SH.M+AB & \begin{tabular}{|l|}
1978 \\
\end{tabular} & 3150 & 3799.6 & 1.4636 & 2275.2 & 29.7 & 646.91 & 0.659 & & 99 \\
\hline Ru-129 & Zubair & U.SH.M & 1982 & 3170 & \begin{tabular}{|l|}
3734 \\
\end{tabular} & 1.4964 & 2573.8 & 32.8 & 779.33 & 0.601 & 0.8002 & 99 \\
\hline Ru-157 & Zubair & $\mathrm{AB}+\mathrm{DJ}+\mathrm{LN}$ & & 3170 & & 1.5327 & 2616.5 & 34 & 814.78 & 0.511 & 0.7941 & 99 \\
\hline Ru-196 & Zubair & U.SH.M & & 3231 & & 1.3329 & 2047.7 & 27.3 & 482.58 & 1.021 & 0.8584 & 99 \\
\hline Ru-227 & Zubair & LN & 1993 & & & 1.4729 & 2403.2 & 33.3 & 701.07 & 0.298 & 0.7639 & 100 \\
\hline Ru-029 & Mishrif & & 1979 & 2318 & 3638 & 1.3229 & 2403.2 & 26.4 & 563.6 & 1.4 & 0.7453 & 76 \\
\hline
\end{tabular}

\section{RESULTS AND DISCUSSION}

Fourteen wells were used to conduct the study in the Mishrif reservoir in North Rumaila oilfield, these thermodynamic studies were collected in the 1970s by South Oil Company, the owner of the field. It was noticed from all the Mishrif samples that saturation pressures vary between 1800 to 2350 psia covering the 14 used wells, In Fig. 2, saturation pressure graduate from the lowest values in the east flank (1800-1900 psi) to the highest values in the west flank (2300$2350 \mathrm{psi}$ ) however the crest of the reservoir has been moderate values of saturation pressure (2150-2000 psi). Physical fluid properties were confirmed as presented in Figs 3, 4, 5, and 6. Therefore, some areas around the flank are observing significant aquifer movement $(>25 \mathrm{~m}$ True 
vertical depth (TVD) in R-474) western North Rumaila, and some areas indicate an immobile aquifer (R-451, R-363) eastern North Rumaila Maybe sort of local digenesis in the aquifer (relatively high Saturation Pressure (Ps)observed at Oil-Water Contact(OWC) in R-363, not observed in R-451) despite both the region-allied in the same spot area. The observations and monitoring area on the eastern flank, shows some areas have aquifer movement whereas other areas show an immobile aquifer. In addition, aquifer monitoring in the east flank and absence of any significant water production, suggests the absence of an active aquifer (BP, 2013) that Maybe be causing the lower pressure on the eastern side gradient to increase in the western side.

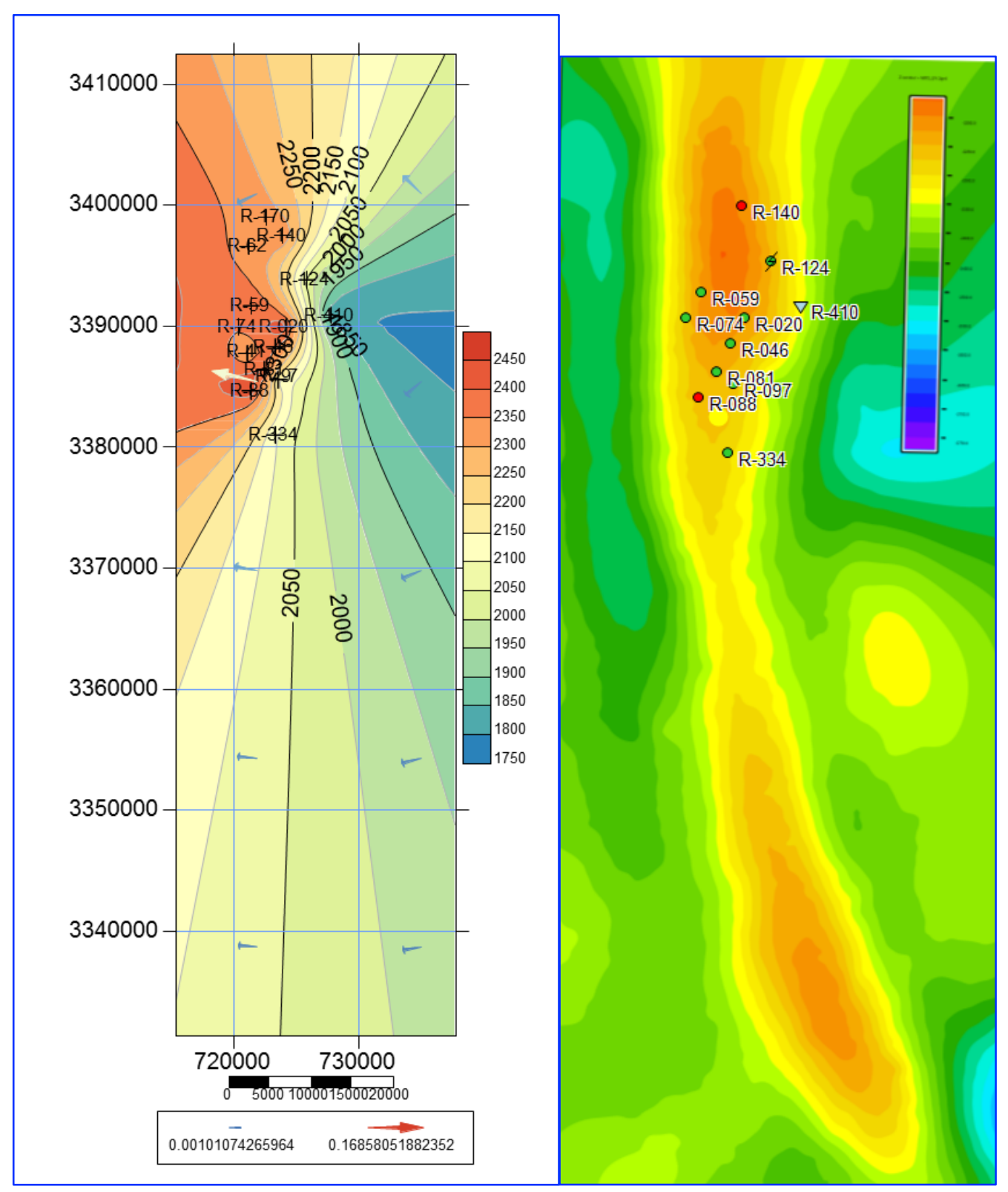

Fig. 2. Saturation pressure gradient of the Mishrif-North Rumaila and wells location 


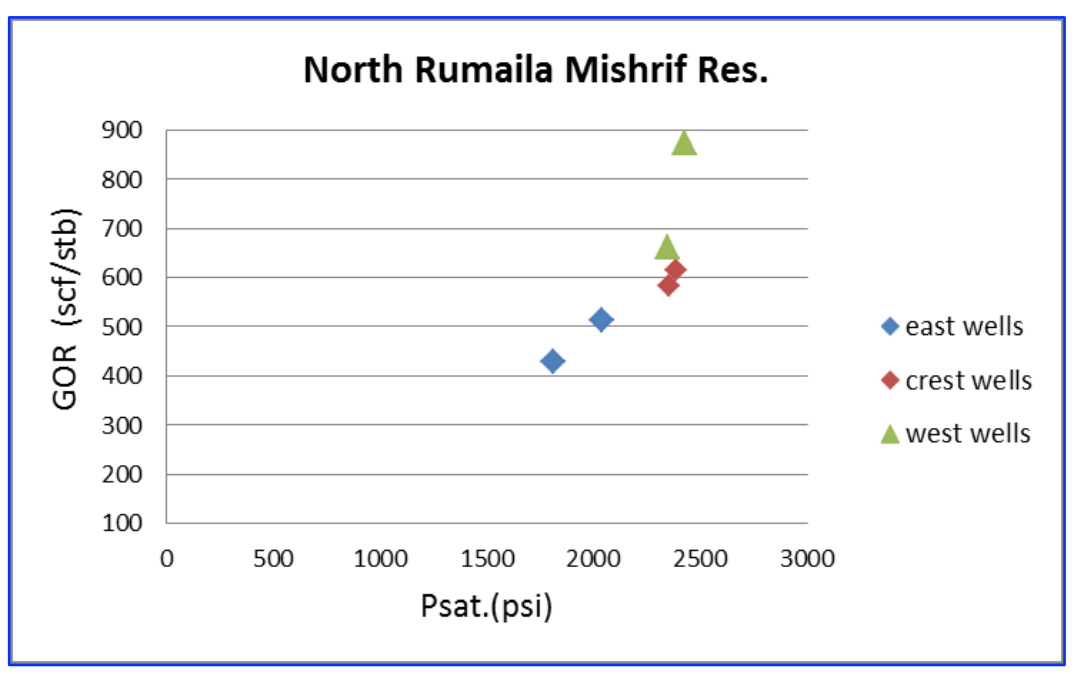

Fig. 3. P sat. vs. GOR for the Mishrif Reservoir-North Rumaila

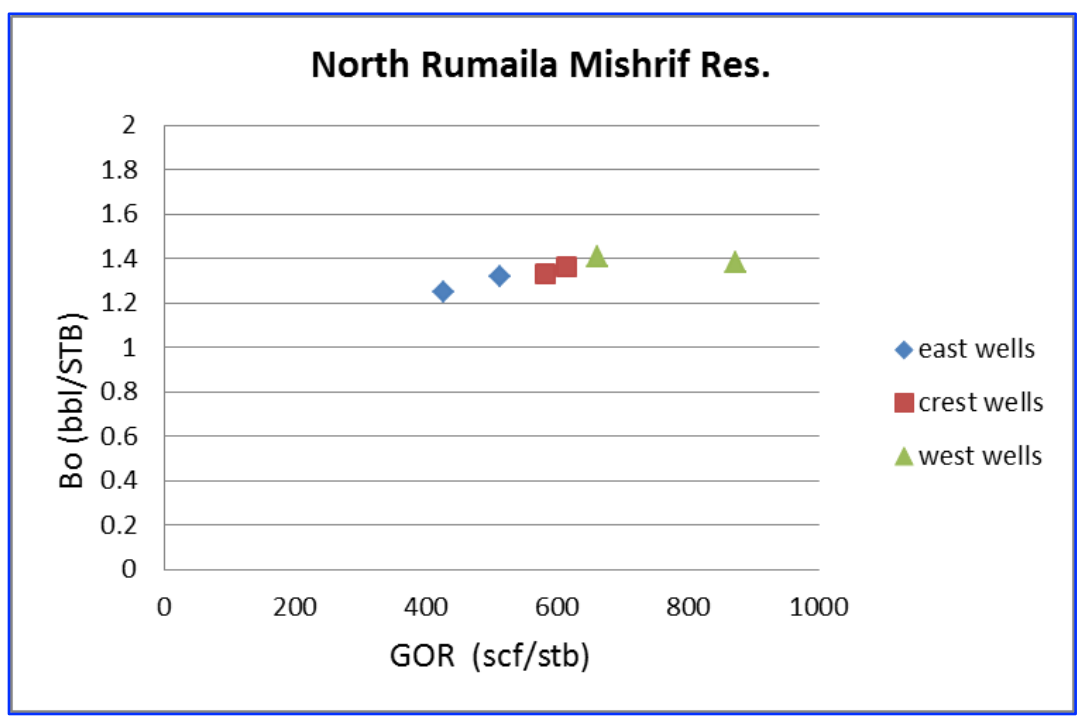

Fig. 4. GOR vs. Bo for the Mishrif reservoir -North Rumaila

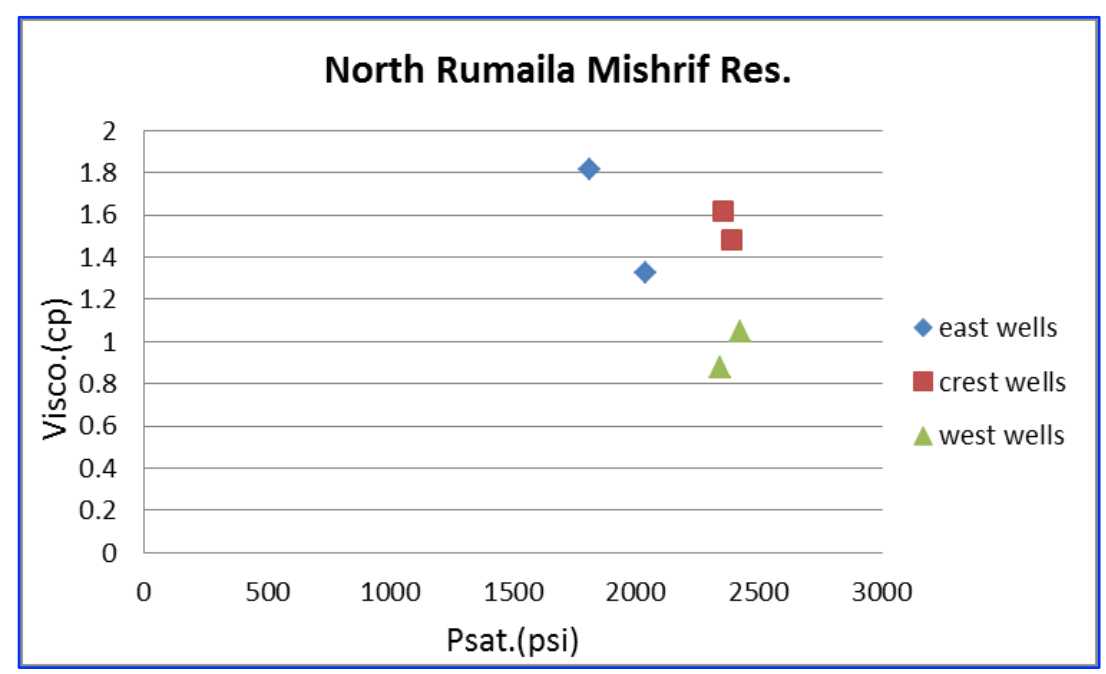

Fig. 5. Psat. vs. Visco. For the Mishrif reservoir -North Rumaila 


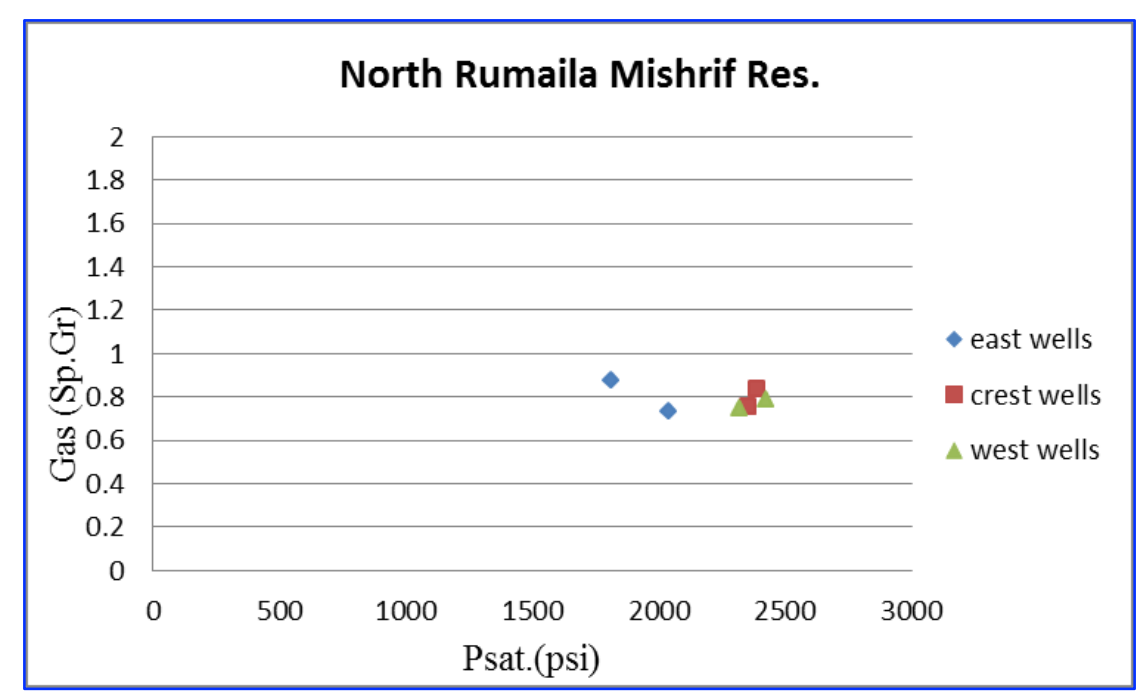

Fig. 6. Psat. vs. gas Sp.Gr. For the Mishrif reservoir -North Rumaila

With more wells covering a larger area of the field and no significant aquifer pressure support, only the extremities of the field retain high pressure, and pressure at the crest of North Rumaila is close to the bubble point ( 2500psi). Recently (2Q 2013) gas has been observed in the $\mathrm{mA}$ of three crestal wells over North Rumaila. The extent of this potential gas cap is being investigated and various plans to reduce pressure loss and potentially re-pressurize should be considered. Fig. 7 showing Shut-in bottom hole pressure (SBHP) reaches saturation pressure (Psat.) On the bases of Psat. of North Rumaila Mishrif Reservoir. However, saturation pressure (Psat.) In the figure equal with the saturation pressure in the west side of Mishrif reservoir in North Rumaila.

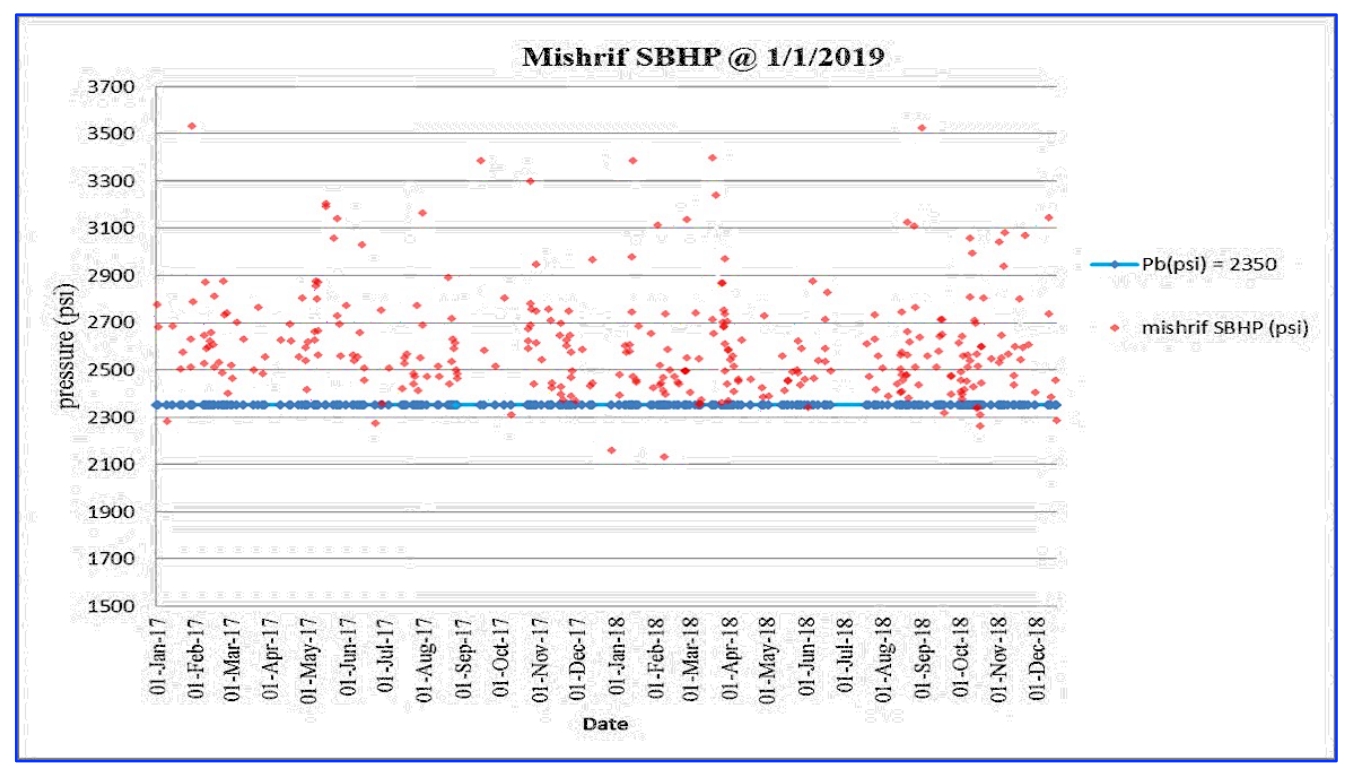

Fig. 7. SBHP vs. Psat. For the Mishrif reservoir-North Rumaila 
Due to the limited number of PVT tests for the Mishrif Reservoir in South Rumaila, it is not possible to fully describe the saturation pressure behavior. However, the average value of pressure (2150 psi) was used in this study. Value of average pressure from two PVT samples in AB unit within Main pay reservoir, North Rumaila is (2770 psi). Nine samples of thermodynamic study and physical properties obtain in DJ unit, all these measurements are located in the crest that indicates saturation pressure greater than (2800) psi (Fig. 8). The similarity of laboratory physical properties $(\mathrm{Pb}$, gas $\mathrm{Sp} . \mathrm{Gr}$, and $\mathrm{API})$ for $\mathrm{AB} \& \mathrm{Dj}$ units are shown in Table 1.
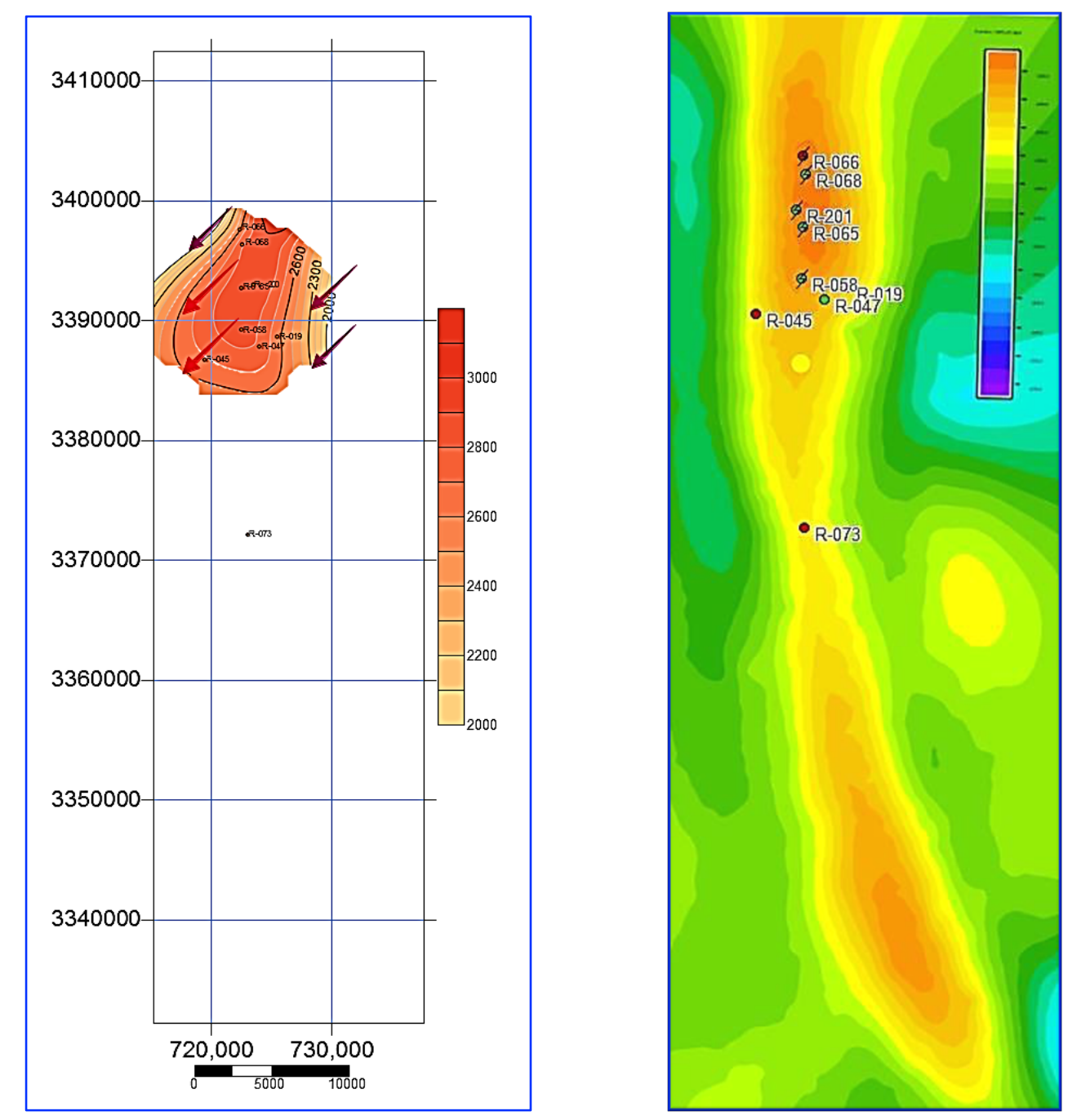

Fig. 8. DJ unit saturation pressure graduate and wells location

Fourteen samples of thermodynamic study and physical properties are available in the deepest LN unit, by mapping distribution of the saturation pressure, it observed that the pressure gradient starts from the northeast side of the north field that records a value of approximately 2000 psi to the southwest side to reach the highest value 2250 psi (Fig. 9). 

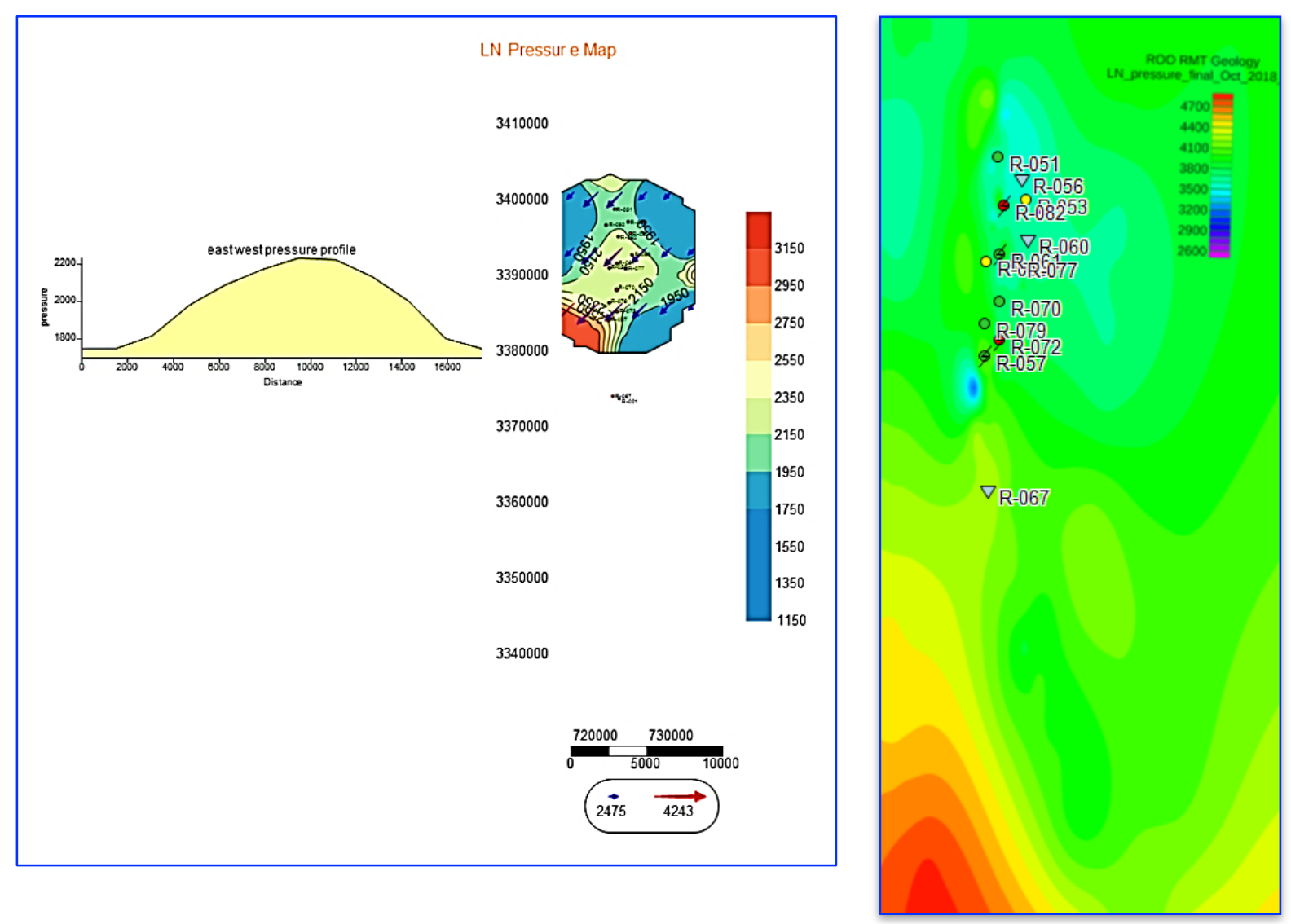

Fig. 9. LN unit saturation pressure graduate and wells location

DJ unit in north Rumaila has values of Psat and GOR higher than LN unit in the same reservoir (Fig. 10). However, according to the stratigraphy, LN unit is deeper than DJ unit, which indicate there is not sufficient change of properties with depth especially Psat. AB unit has intermediate values of Psat. However, the same result for GOR vs. Formation volume factor and other properties (Figs. 10, 11, 12 and 13).

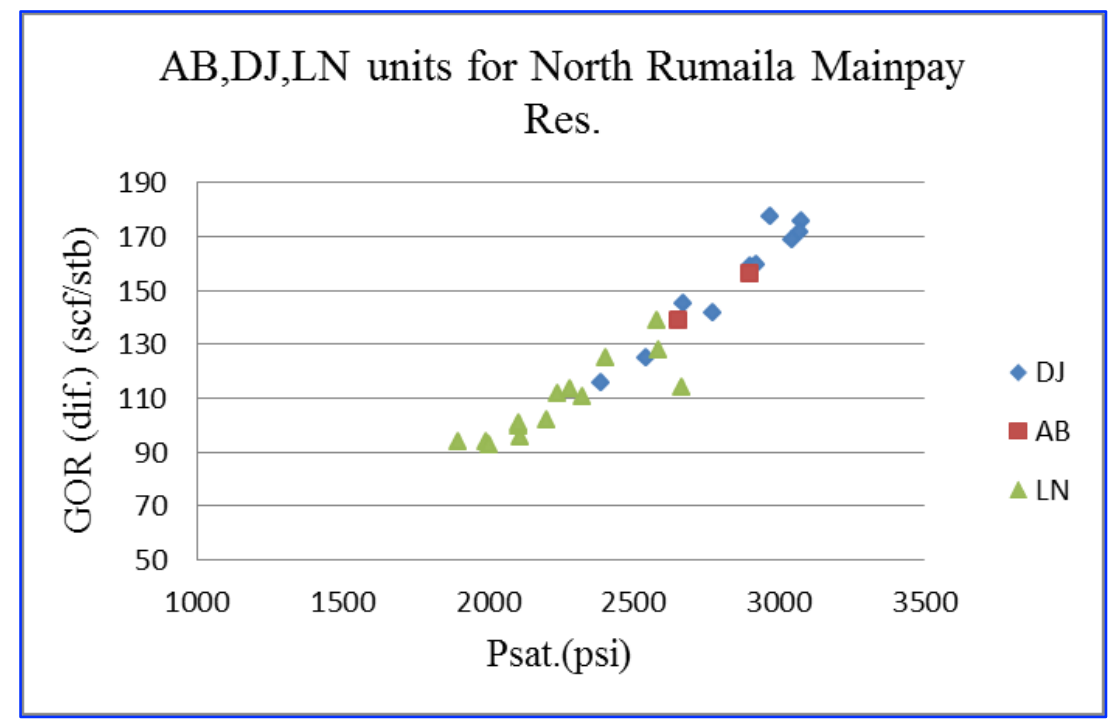

Fig. 10. Psat. Vs. GOR for the Main pay unit 


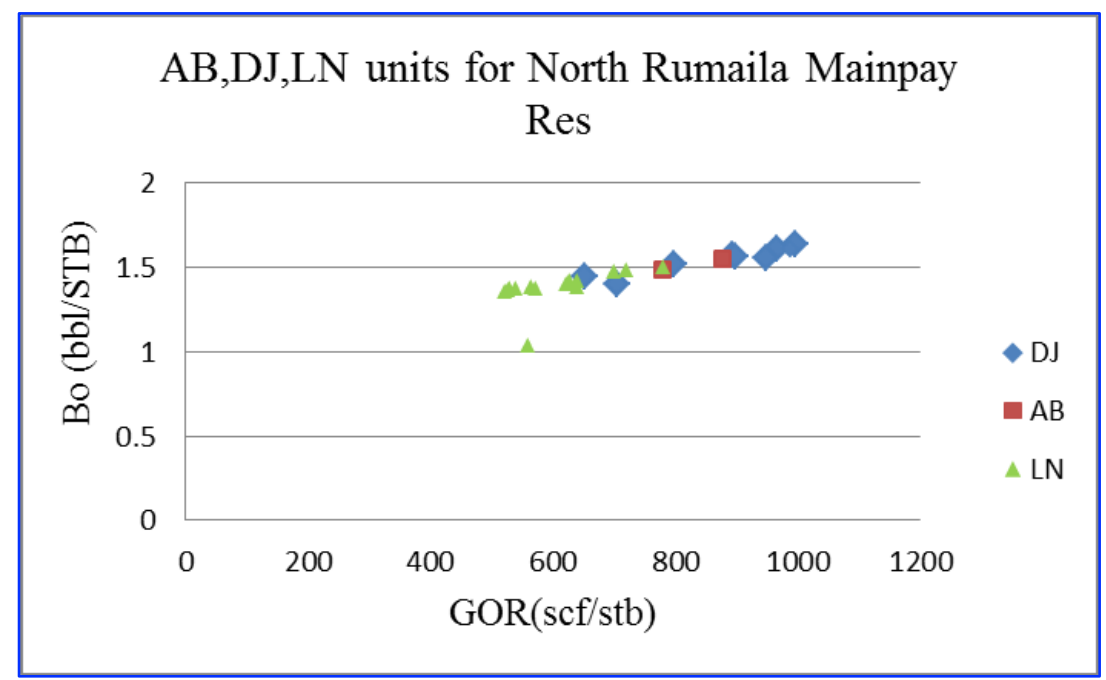

Fig. 11. GOR. Vs. Bo for the Main pay unit

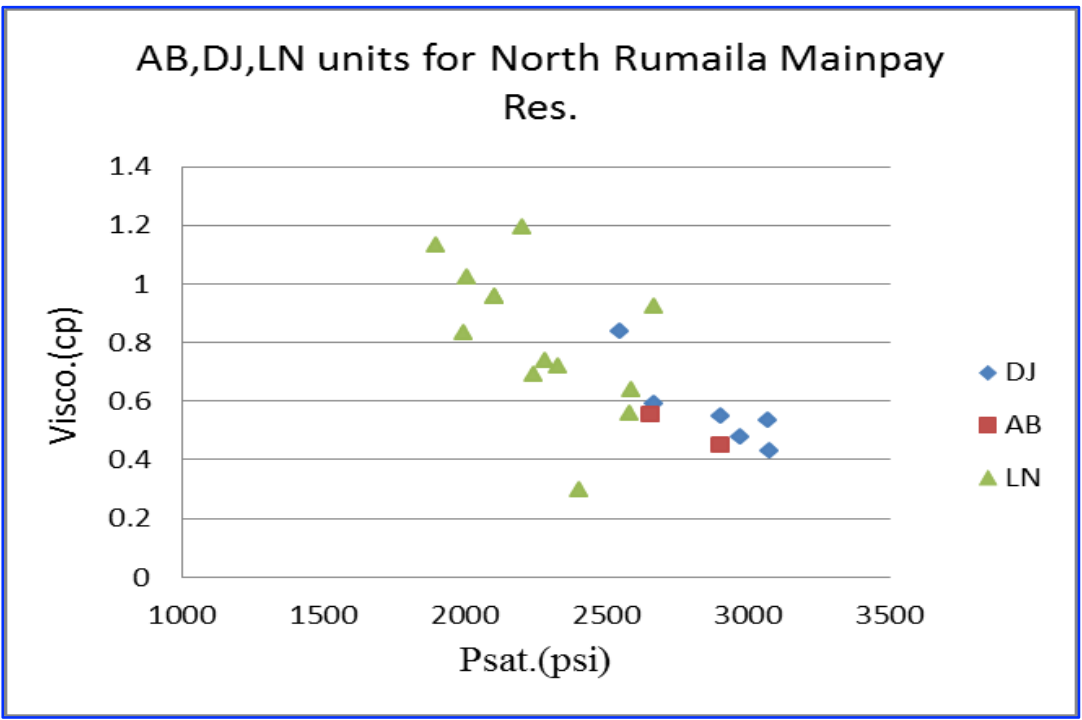

Fig. 12. Psat. Vs. Viscosity for the Main pay unit

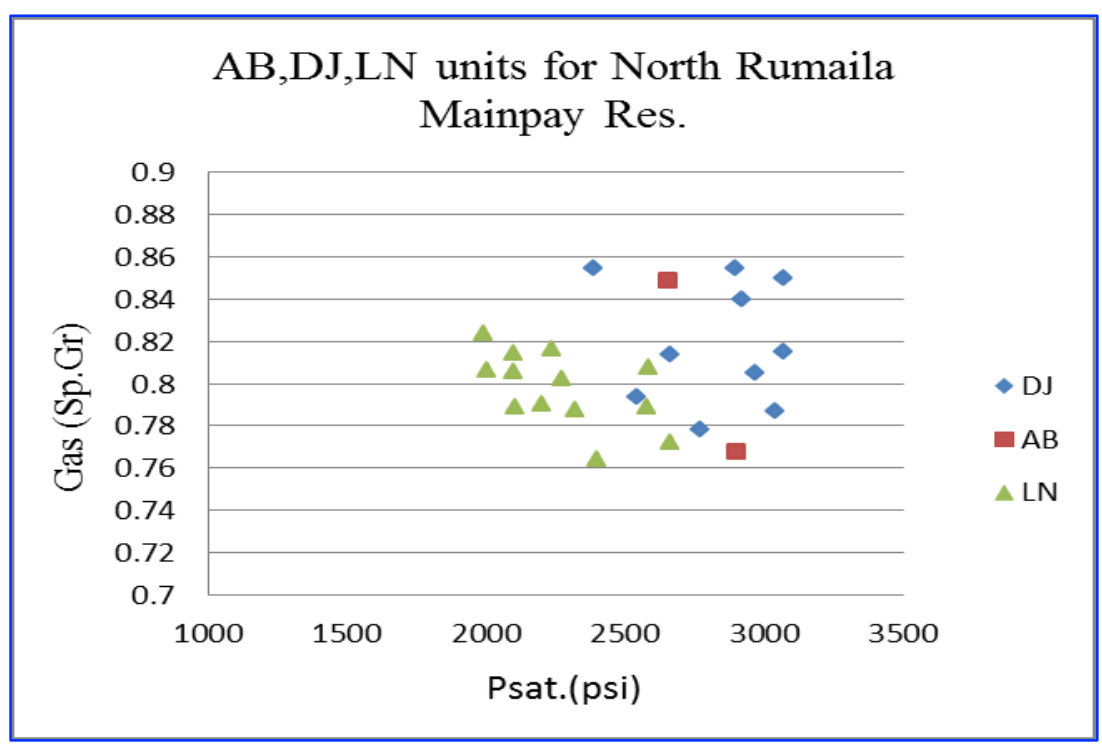

Fig. 13. Psat. Vs. Gas (Sp.Gr) for the Main pay unit 
Eleven fluid samples of (PVT) merge AB with DJ units, the pressure values appear to be similar in the opposite regions, whereas the pressure rises in the north-east and south-west regions, while falling sharply in the south-east and north-west regions (Fig. 14). Five samples well thermodynamic study and physical properties obtain AB, DJ and LN simultaneously that cannot conduct a plot to describe pressure behavior in the reservoir extension, however, through the five tests, it is possible to give a moderate value of saturation pressure 2270 psi. six samples of wells laboratory physical properties occupy DJ with LN units obtain a moderate value of pressure 2280 psi. 9 samples of thermodynamic study and physical properties are available in the upper shale reservoir, south Rumaila. all these samples collect in the ultimate southeast part of Rumaila, by dropping the pressure values on the map, the saturation pressure is set to approx. 2300psi (Fig. 15).
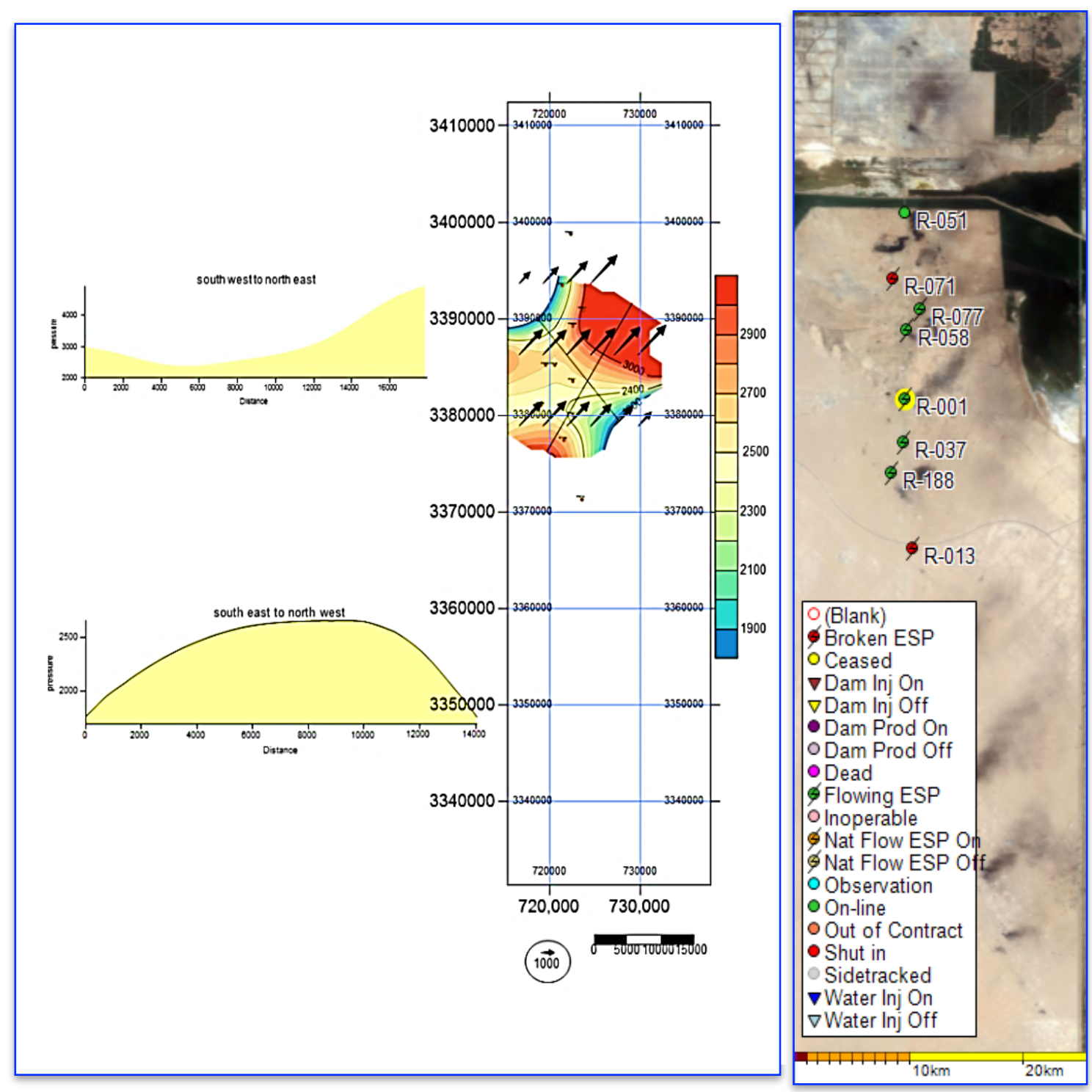

Fig. 14. Saturation pressure graduate for ABDJ unit and wells location 


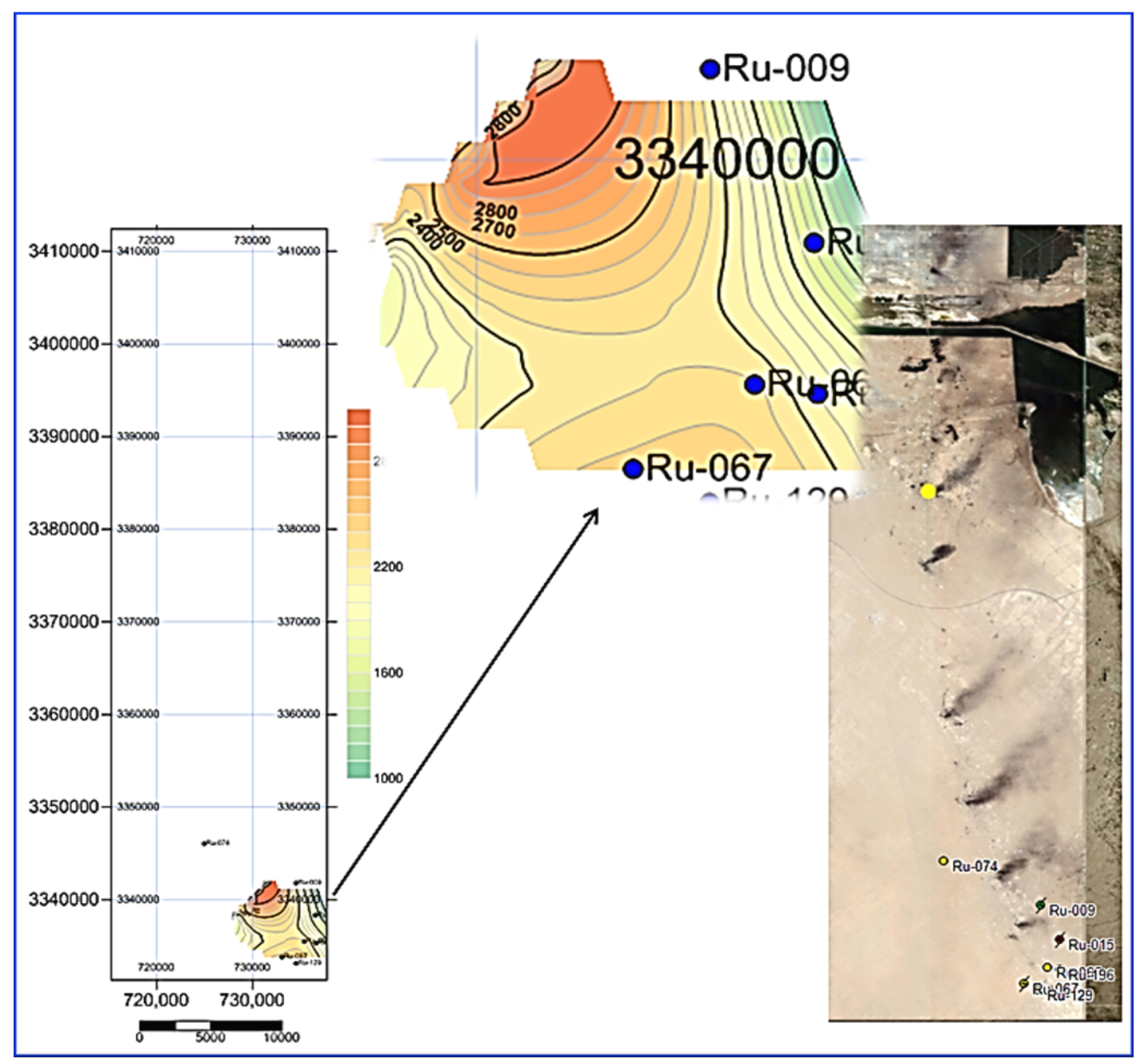

Fig. 15. Saturation pressure gradient, Upper shale reservoir, South Rumaila and wells location

In Figs. 16 and 17 plotting Psat vs. GOR for two fields (south and north Rumaila) Mishrif, Main pay reservoir show that all data follow one straight line indicated that all fluid behaves as an admixture of one oil type. In the Mishrif reservoir, the saturation pressure in North Rumaila is higher than in the south that the extent of the Mishrif oil accumulation over Rumaila is regarded as a stratigraphic trap. In the Mishrif of the southernmost part of the Rumaila structure, the reservoir carbonates are regarded as tighter. Therefore, the distribution of oil is related to the maximum extent of shallow carbonate deposits with reservoir quality. The best reservoir quality carbonates are restricted to the northern Rumaila, reflecting the extent of the shallow water platform at the time (Al-Mimar and Awadh, 2019). PVT analysis on fluid samples shows the presence of undersaturated oil phase, without a gas cap, before field production started. Oil samples from individual wells reveal saturation pressures that range from 1800 to 2570 psia. This is in comparison with an initial reservoir pressure of $\sim 3900$ psia. The high temperature in the reservoir will increase the pressure and contribute to the fluid movement (Ahmed, 2018) 
the temperature of the reservoirs included in the research is constant for all studied wells, although oil gravity is constant, which represented as API. Table 1 shows the main and sub reservoir of Rumaila oil field with reservoir temperature.

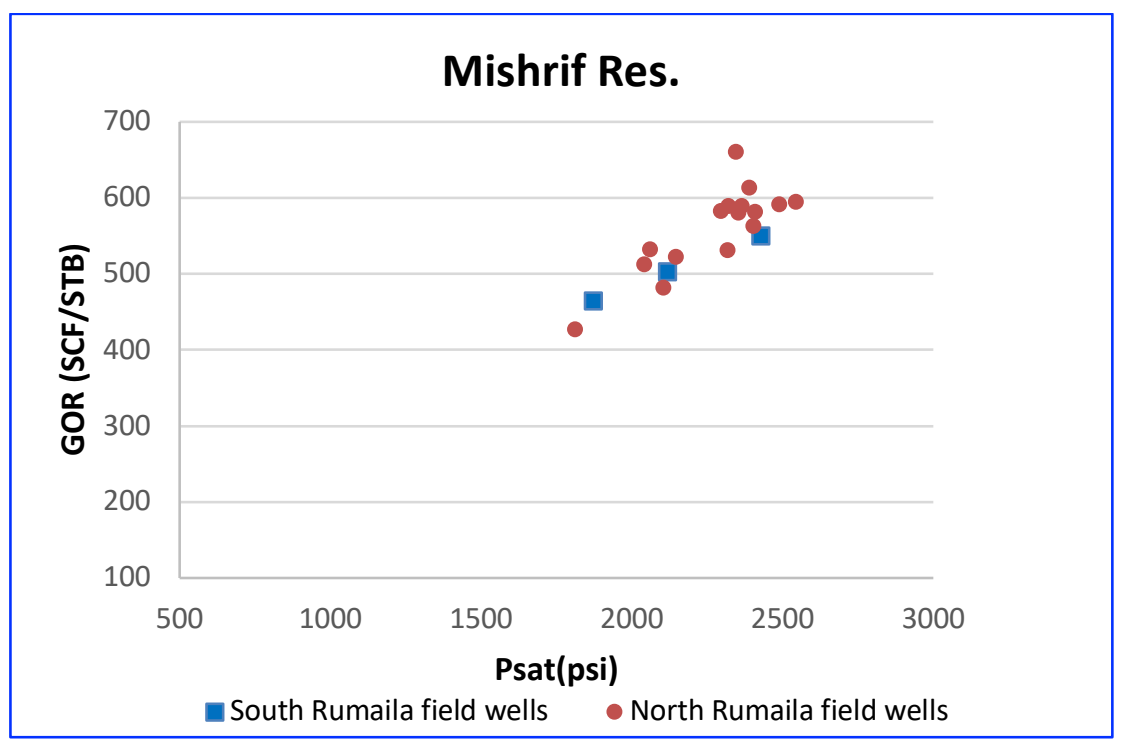

Fig. 16. Psat vs. GOR for south and north Rumaila Mishrif reservoir

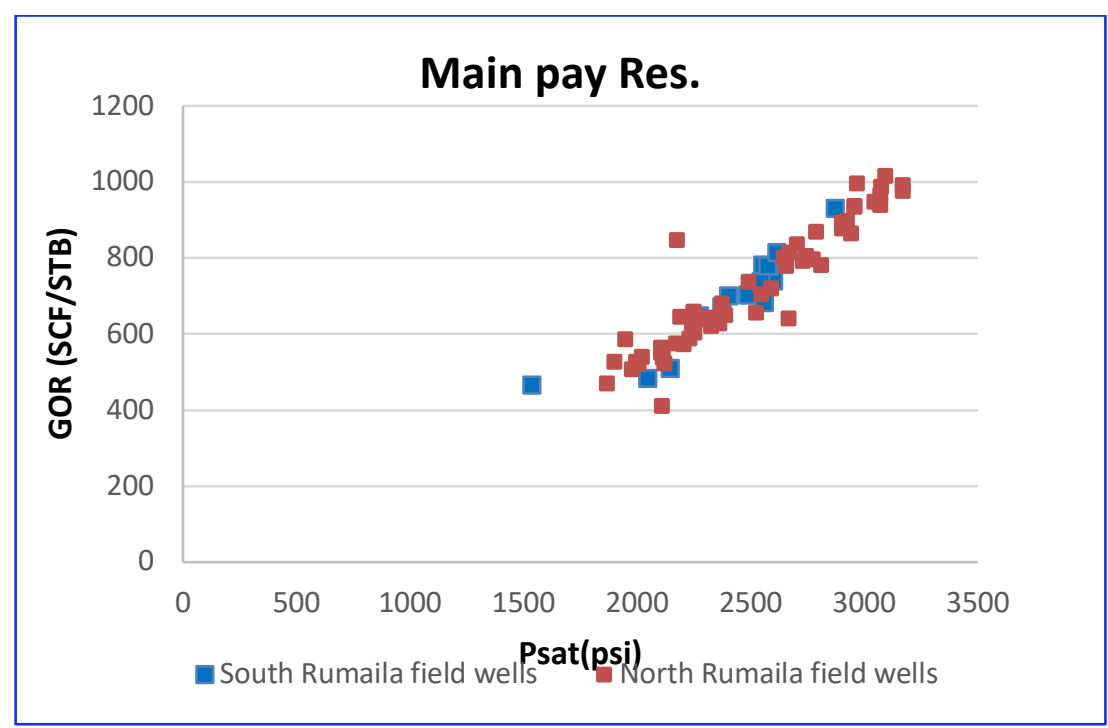

Fig. 17. Psat vs. GOR for south and north Rumaila Main pay reservoir

Table 2. Temperature and API oil gravity (BOC report unpublished)

\begin{tabular}{|l|c|c|c|}
\hline Reservoir & Field & Temperature $\left({ }^{\circ} \mathbf{C}\right)$ & API \\
\hline \multirow{2}{*}{ Zubair Fm. Main pay unit } & North Rumaila & 98.9 & $28-33$ \\
\cline { 2 - 4 } & South Rumaila & 99 & 33 \\
\hline \multirow{2}{*}{ Mishrif } & North Rumaila & 76 & 25.5 \\
\cline { 2 - 4 } & South Rumaila & 81 & 26 \\
\hline Zubair Fm. Upper shale member & South Rumaila & 99 & 30 \\
\hline
\end{tabular}




\section{CONCLUSIONS}

1. With many wells covering a large area of the field that depleted original reservoir pressure and no significant aquifer pressure support, such as the North Rumaila Mishrif reservoir, the reservoir pressure is close to the bubble point pressure $(\sim 2350)$, particularly in the west flank.

2. The saturation pressure of the North Rumaila Mishrif graduates from the lowest values in the east flank to the highest values in the west flank.

3. In the Mishrif reservoir, the saturation pressure in west flank North Rumaila is higher than in the south, the extent of the Mishrif oil accumulation over Rumaila is regarded as a stratigraphic trap.

4. North Rumaila main pay units are AB, DJ, LN, DJ has higher Psat than the LN unit.

\section{RECOMMENDATIONS}

For the purpose of covering the whole field and depleted pressure areas with physical properties, new tests are suggested to take in some wells distributed according to reservoir type as shown in (Table 3), Resumption the research by studying the geologic nature and reason for moderate bubble point pressure within the same layer.

Table 3. Suggested wells for the future thermodynamic study and physical properties

\begin{tabular}{|c|c|c|c|c|}
\hline Field & Reservoir & Well no. & Easting & Northing \\
\hline \multirow{17}{*}{ North Rumaila } & \multirow{8}{*}{ Mishrif } & 442 & 722365.36 & 3375545.51 \\
\hline & & 430 & 718721.55 & 3386408.46 \\
\hline & & 353 & 725917.95 & 3388211.4 \\
\hline & & 228 & 729522.15 & 3395413.4 \\
\hline & & 391 & 718719.62 & 3396312.66 \\
\hline & & 412 & 723185.7 & 3392711.04 \\
\hline & & 627 & 718683.8 & 3398363.3 \\
\hline & & 217 & 728620.63 & 3399014.35 \\
\hline & \multirow[t]{9}{*}{ Main pay } & 517 & 722023 & 3377822 \\
\hline & & 635 & 721389.8 & 3383166.8 \\
\hline & & 172 & 723070 & 3394761.92 \\
\hline & & 86 & 721485.82 & 3406012.66 \\
\hline & & 564 & 725470.6 & 3396945.9 \\
\hline & & 49 & 721061.79 & 3398158.72 \\
\hline & & 582 & 723091.1 & 3391843.6 \\
\hline & & 547 & 723027.23 & 3385089.19 \\
\hline & & 635 & 721389.8 & 3383166.8 \\
\hline \multirow[t]{9}{*}{ South } & \multirow[t]{4}{*}{ Mishrif } & 417 & 728156.8 & 3346497.48 \\
\hline & & 128 & 731046.74 & 3350700.23 \\
\hline & & 322 & 723216 & 3358513 \\
\hline & & 431 & 728021.93 & 3367569.83 \\
\hline & \multirow[t]{5}{*}{ Main pay } & 148 & 724975.39 & 3365222.67 \\
\hline & & 442 & 730485.1 & 3349820.2 \\
\hline & & 416 & 730872 & 3342992 \\
\hline & & 33 & 730499.25 & 3338356.9 \\
\hline & & 258 & 734991.84 & 3337481.85 \\
\hline
\end{tabular}




\section{REFERENCES}

Ahmed, T., 2018. Reservoir Engineering Handbook. Gulf Professional Publishing

Al-Jafar, M. K., and Al-Jaberi, M. H., 2019. Well logging and electrofacies of Zubair Formation for Upper sandstone member in Zubair oilfield, Southern Iraq. Iraqi Geological Journal, 53(1): 101-125.

Almayyahi, H. K., and Aljaberi, M. H., 2018. Sedimentological study for the Upper Shale member in Zubair Formation to enhance and comparison oil production in North Rumaila oilfield. Modeling Earth Systems and Environment, 4(3): 981-1006.

Al-Mimar, H. S., and Awadh, S. M., 2019. The role of chemistry of the oilfield water in the distribution of reservoir Pressures: a case study of Mishrif reservoir in the Southern oilfields. Journal of Petroleum Research and Studies, (22): E52-E64.

Al-Mudhafar, W. J., 2017. Geostatistical lithofacies modelling of the upper sandstone member, Zubair Formation in south Rumaila oilfield, Iraq, Arabian Journal of Geoscience, 10(6):153.

Arif, R. K., and Khaffaf, S. T., 1979. Geological study of Luhais Field Iraq, National Oil Company-Baghdad (unpublished Report).

Basra oil company, 2016 review document (unpublished report).

BP, 2013. Integrated subsurface description (ISD): Mishrif Rumaila Field, SE Iraq (unpublished report).

Karim, H. H., 1992. Structural nature of lower Mesopotamian region from geophysical observations, University of Basra. Marine Science Center: 14-26.

Morad, N. M., Afaj, A. H. and Abass, M. A., 1989. Sedimentological study of Zubair Formation in field of Luhais in wells 4 and 8, University of Basrah (unpublished Report). No16, P16.

Vetter, O. J., and Farone, W. A., 1987. Calcium carbonate scale in oilfield operations. In SPE Annual Technical Conference and Exhibition. Society of Petroleum Engineers. 